\title{
JURISPRUDENCIA ADMINISTRATIVA
}

\section{ACÓRDÃo}

\section{Supremo Tribunal Federal}

\section{RECURSO ORDINÁRIO EM MAN- DADO DE SEGURANÇA N* 9.992 - DISTRITO FEDERAL}

Reclassificação de cargos não beneficia os aposentados anteriormente, porque não equivale à revisão de proventos regulada na Lei $n^{\circ}$ 2.622, de 18-9-55.

Relator: O Sr. Ministro Vilas Boas.

Recorrente: Orthogamizo de Magalhães .

Recorrida: União Federal.

\section{ACÓRD̃̃o}

Vistos, relatados e discutidos os autos acima identificados, acordam os $\mathrm{Mi}$ nistros do Supremo Tribunal Federal, em sessão plenária, na conformidade da ata do julgamento e das notas taquigráficas, por maioria de votos, negar provimento ao recurso.

Brasilia, 28 de setembro de 1962 (data do julgamento). - Lafayette de Andrada, Pres:dente. - Victor Nunes Leal, Relato:

\section{RELATÓRIO}

O Senhor Ministro Vilas Boas O recurso foi interposto contra acórdãa que, cassando o writ outorgado a Orthogamizo de Magalhães, se subordina a esta ementa: "Alcance da Lei número 2.622-55, para os fins da revisão de proventos de aposentadoria".

A douta Procuradoria-Geral da República opina pela confirmação.

\section{vото}

O recorrente se aposentou em 1939 , como Motorista G, do Quadro da Secretaria do Supremo Tribunal Federal. cargo que corresponde hoje, como certifica o Sr. D:. Diretor-Geral, ao padrão M (fls. 9).

O M. Juiz havia defer:do ampla equiparação, conforme o pedido, inclusive aumento de gratificação.

Outra, porém, foi a decisão do Egrégio Tribunal Federal de Recursos.

Vejamos.

A revisão é imperativo constitucional $e$ tem por indice os vencimentos dos funcionários em atividade (Constituição, artigo 193).

A Lei $\mathrm{n}^{2} 2.622$, mais positivamente, preceitua:

"Art. 10 O cálculo dos p:oventos dos servidores civis da União, e bem assim dos servidores das entidades autárquicas ou paraestatais que se encontram na inatividada e dos que para ela forem transferidos, será feito à base do que perceberem os servidores $\mathrm{cm}$ atividade, a fim de que seus proventos sejam sempre atualizados".

E' claro o texto: atualização por isonomia ou igualitarismo.

A operação começa com uma pesquisa que dará resposta à pergunta se êsse servido: não estivesse aposentado, qual seria a sua pos.ção atual?

Faço naturalmente abstração da carreira, por se tratar de cargo isolado.

$E^{\prime}$ que o funcionário se aposenta com os vencimentos que a lei da época fixa em correspondência com o seu título, observado necessàriamente 0 tempo de serviço (artigo 191, $\S 2^{\circ}$ ).

$\mathrm{S}_{2}$ o título do companheiro que continua não é substituido por outro, modificando-se apenas o valor numérico da remuneração (quem era $\mathrm{G}$, naquele momento, agora é $\mathrm{M}$ ), evidentemente essa melhoria beneficia, também, nos 
têrmos da lei, ao inativo, mesmo porque não há outro critério para a revisão.

Dou provimento em parte ao recurEo, nara conceder a equiparação, menos quanto à gratificação adicional. pois, essa fica sem alteração (artigo $2^{\circ}$ ca Lei).

\section{VISTA}

O Senhor Ministro Victor Nunes - Senhor Presidente, peço vista dos autos.

\section{DECISÃO}

Como consta da ata, a decisão foi ia seguinte: Depois do voto do Relator danda provimento, em pate, ao recurso, o Ministro Victor Nunes pediu vista dos autos.

Relator: o Exmọ Senhor Ministro Villa Boas.

Presidênc'a do Exmọ Senhor Miinistro Lafayette de Andrada.

Ausentes, justificadamente, os Exce'lentissimos Srs. Ministros Gonçalyes de Oliveira, Cândido Motta Filho c Ary Franco. - Hugo Mosia, Vice. Diretor-Ge:al.

\section{voTo \\ (Vista)}

O Senho: Ministro Victor Nunes -. Data venia do eminente relator, nego provimento ao recurso. O principio geral, tantas vêzes reiterado no Supremo Tribunal (inclusive, recentemen. te, nos embargos 35.059, de 9-1-61, relator o eminente Ministro Ary Franco), é que os beneficios da aposentadoria são os da lei vigente ao tempo da concessão. Pode-se entender êsse principio, razoàvelmente, como indicando a lei do tempo em que a interessado, pela reunião dos requisitos necessários, adquiriu o direito à aposentadoria. Assim se evitará, por exemplo, quz em caso de aposentadoria compulsória o administrador retarde a exped ção do ato, à espera de uma lei em elaboração, que lhe desse menores proventos do que os previstos na lei vigente na data em que se realizou a condição a que estava subor- dinada a aposentadoria. Entretanto, não é disso que se trata nos presentes autos.

Aqui, pretende o recor:ente beneficiar-se de uma interpretação extensiva do principio da revisão dos proventos dos inativos, inscrito na Constituição, artigo 193, e regulado na Lei $\mathrm{n}^{2} 2.622$, de 18-10-55. Mas, no caso, não se trata de simples majoração de vencimentos, que pudesse favorecer o racor:ente. Houve autêntica reclassificação do cargo em que foi o recorrente aposentado - Motorista - o qual passou do padrão "L" para o padrão " $M$ ".

A reclassificação atinge apenas os servidores em atividade, não os aposentados, porque é coisa bem diversa de majoração de vencimentos, que pudesse dar origem à revisão de proventos.

Mantenho, data venia, a decisão recorrida, do Tribunal Federal de Recursos, tomada à base do voto do eminente Ministro Oscar Saraiva.

\section{DECISÃO}

Cơmo consta da ata, a decisão foi a seguinte: Negaram provimen:o contra o voto do Ministro Relator.

Presidência do $\mathrm{Ex}^{\mathrm{m}} \mathrm{e}$ Senhor Mínistro Lafayette de And:ada.

Relator: o Exm ${ }^{\mathrm{m}}$ Senho: Ministro Villas Boas.

Ausente, justificadamente, o Excelentissimo Senhor Ministro Luiz Gallotti.

Não votou o Exmọ Senhor Ministro Ary Franco, por não ter assistido ao relatório.

Toma-am parte no julgamento os Ex ${ }^{m}{ }^{s}$ Senhores Ministros Cunha Mello (substituto do Exmo Senhor Ministro Barros Barreto), Pedro Chaves, Victor Nunes, Gonçalves de Oliveira, Villas Boas, Cândido Motta Filho, Hahnemann Guimarães e Ribeiro da Costa. - Daniel Aarão Reis, Diretor da Bibl'oteca, em substituição ao Dr. Hugo Mosca, Vice-Diretor-Geral, no exercicio da Diretoria Geral.

D. O. de 22-11-62. 